\title{
THE PROTECTIVE EFFECT OF MATERIALS EXTRACTED FROM BACTERIAL CELLS AGAINST INFECTION IN EXPERIMENTAL SALMONELLOSIS
}

\author{
1. PROTECTION WITH PHENOL EXTRACT
}

\author{
YOSHISATO HAGIHARA, MITSUKO SASAKI, AND SACHIKO HONMA \\ Department of Microbiology, Kurume University School of Medicine, \\ Kurume, Japan
}

(Received for publication July 16, 1973)

\begin{abstract}
The protective effect of living as well as killed cells and phenol extracts obtained from an attenuated strain of Salmonella enteritidis against infection with a virulent strain in mice were studied. Results summarized as follows.

1. Killed cells of an attenuated strain had no protective effect against infection with a virulent strain, though living cells were remarkably effective.

2. Eight fractions were obtained from an attenuated strain by extraction with phenol. A large amount of RNA and a small amount of DNA with protein were contained in these fractions.

3. It was shown that fraction I and IV extracted with phenol $\mathrm{pH} 4$ had some protective effects against infection, but the remaining fraction I-D, III and all of the fractions extracted with phenol $\mathrm{pH} 6$ were ineffective.
\end{abstract}

It has been known that killed vaccine of Salmonella enteritidis is ineffective in preventing ultimate death from infection with a virulent strain. On the contrary, suitable immunization with living vaccine can protect against infection $^{1)}$. Kawakami et al. ${ }^{2)}$ reported on the immunizing effect of materials isolated from Salmonella enteritidis against infection with the same strain. On the other hand, Youmans et al. ${ }^{3)}$ 4) and Venneman et al.5) reported that ribosomal fraction showed protective effect against infection. This paper concerns attempts to study on the protective effect of phenol extract obtained from bacterial cells against infection in experimental Salmonellosis.

\section{MATERIALS AND METHODS}

Bacteria. A virulent strain 116-54 (116 strain) and an attenuated strain SER-18 M (18M strain) of Salmonella enteritidis acquired from Dr. Mitsuhashi, Department of Microbiology, Gunma University School of Medicine, Maebashi, were used.

Experimental animals. Female mice of dd-N strain, weighing about $20 \mathrm{gm}$ were used throughout this experiment.

Preparation of immunizing materials. Viable cell suspension of the $18 \mathrm{M}$ strain in physiological saline was prepared from overnight culture on agar slant, and adjusted to adequate concentration by using a densitometer. Heat 
killed cells of the $18 \mathrm{M}$ strain were prepared by heating at $100^{\circ} \mathrm{C}$ for $30 \mathrm{~min}$. Phenol extracts were prepared by the modified method of Shibatani et al. ${ }^{6}$, Ingle et al. ${ }^{7}$ and Georgiev et al. ${ }^{8}$ Cells of the $18 \mathrm{M}$ strain cultured at $37^{\circ} \mathrm{C}$ overnight in five flasks containing $200 \mathrm{ml}$ of heart infusion broth (HIB) were respectively pored into five flasks containing $1,500 \mathrm{ml}$ of fresh HIB kept at $37^{\circ} \mathrm{C}$. After cultivation at $37^{\circ} \mathrm{C}$ for 1 hour and addition of $7.5 \mathrm{gm}$ of bentonite, bacterial cells were collected by centrifugation, and washed once with $10 \mathrm{mM}$ tris buffer $\mathrm{pH} 7.4$ containing $0.15 \mathrm{M} \mathrm{NaCl}$ (tris- $\mathrm{NaCl}$ ). To the bacterial suspension in $170 \mathrm{ml}$ of the same buffer, $35 \mathrm{ml}$ of $25 \%$ sodium laulyl sulphate was added, and the mixture was stirred in ice for about 1 hour. Two hundred $\mathrm{ml}$ of $80 \%$ phenol which contained tris- $\mathrm{NaCl}$ at the concentration of $20 \%$ (listed as phenol $\mathrm{pH} 4$ ) was further added, and stirred in ice for $15 \mathrm{~min}$. The phenol adjusted to $\mathrm{pH} 6.0$ with $1 \mathrm{~N} \mathrm{NaOH}$ was used for extraction, and this phenol was listed as phenol $\mathrm{pH} 6$.

After centrifugation at $10,000 \mathrm{~g}$ for $15 \mathrm{~min}$, aqueous phase was removed, and designated as Fraction I. The denaturated protein between aqueous phase and phenol phase, and a centrifugated residue, were respectively resuspended in $30 \mathrm{ml}$ and $70 \mathrm{ml}$ of tris- $\mathrm{NaCl}$. After heating at $70^{\circ} \mathrm{C}$ for $15 \mathrm{~min}$ and mixing with $80 \%$ phenol for $15 \mathrm{~min}$, these mixtures were centrifugated, and two removed aqueous phases were designated as Fraction III and IV, respectively.

These three fractions were further deproteinated with equal volume of $80 \%$ phenol 3 to 5 times, and nucleic acids were precipitated by addition of 2 volumes of cold ethanol. After standing at $-20^{\circ} \mathrm{C}$ overnight, the precipitates were collected by centrifugation and washed with a series of ethanol, and dried by suction. A flocculent precipi- tate occured in Fraction I was separated, washed in the same manner, and designated as Fraction I-D.

Chemical analysis. Ribonucleic acid (RNA) was estimated by the modifed orcinol $\operatorname{method}^{2)}$, and deoxyribonucleic acid (DNA) and protein by the method of Dishe ${ }^{10)}$ and Lowry ${ }^{11)}$, respectively.

Immunization. Each group containing 10 mice was used for immunization. The mice recieved immunizing materials by intramuscular injection on femur or on femur and upper arm.

A one tenth $\mathrm{ml}$ of suspension of viable cells and killed cells of the $18 \mathrm{M}$ strain was only once injected for immunization

The phenol extract was dissolved in tris- $\mathrm{NaCl}$ at the concentration of 10 $\mathrm{mg} / \mathrm{ml}$ as RNA. To this solution, a half volume of $20 \mathrm{mg} / \mathrm{ml}$ of methylated bovine serum albumin was added and mixed, and one and half volumes of Freund's complete adjuvant was further added ${ }^{12)}$. A three tenth of this mixture was administered to mice. Five weeks later, the second immunization was carried out by the same procedure.

Challenging infection. A one tenth $\mathrm{ml}$ of suspension containing $1 \times 10^{4}$ to $1 \times 10^{5}$ cells of the 116 strain cultured on agar slant at $37^{\circ} \mathrm{C}$ overnight was intraperitoneally injected for challenging infection 3 weeks after the last immunization.

\section{RESULTS}

1. Virulence of 116 strain and $18 M$ strain. The virulence of the 116 strain of Salmonella enteritidis was examined by intraperitoneal injection to mice. The results are shown in Fig. 1. No mice injected with $6.6 \times 10^{3}$ and more than cells of the 116 strain survived over 10 days. On the other hand, all of the mice injected with under $1.4 \times 10^{6}$ cells of the $18 \mathrm{M}$ strain survived over 30 days. 
2. Protective effects of living and killed cells of the 18M strain against infection with the 116 strain. Mice immunized with living cells of the $18 \mathrm{M}$ strain were strongly resistant against

The $18 \mathrm{M}$ strain

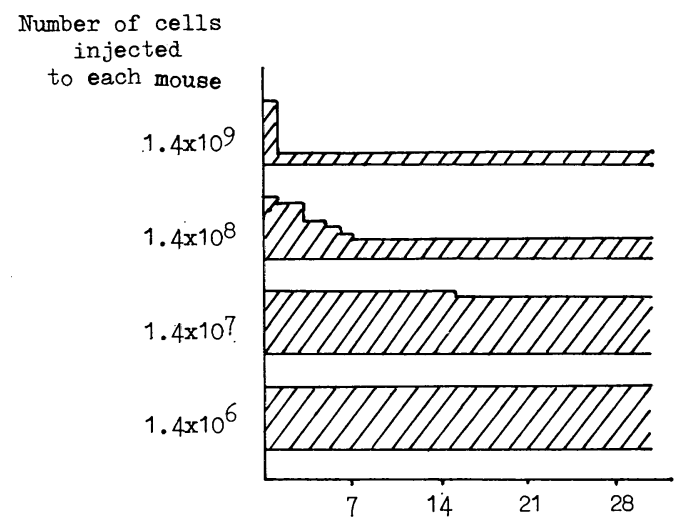

Days after infection infection with $1 \times 10^{4}$ cells of the 116 strain, but all mice immunized with killed cells died within 10 to 15 days (Fig. 2).

The 116 strain

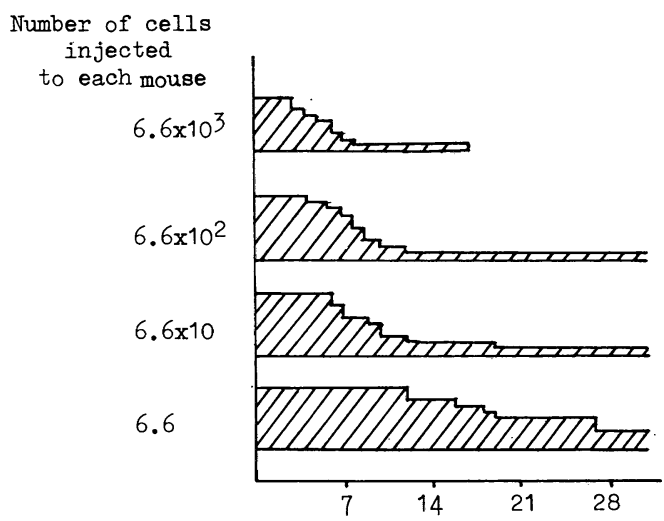

Days after infection

Fig. 1 Pathogenicity of the $18 \mathrm{M}$ strain and the 116 strain of S. enteritidis in mice.

Living cells of the $18 \mathrm{M}$ strain

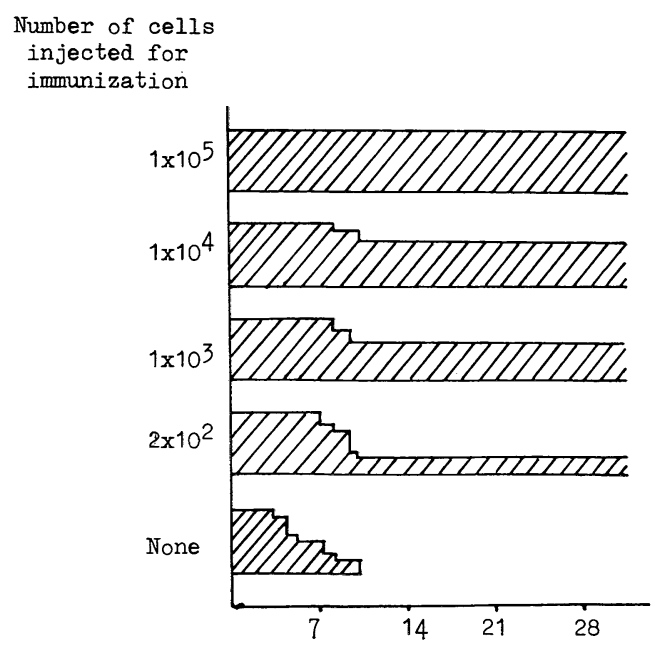

Days after infection
Killed cells of the $18 \mathrm{M}$ strain

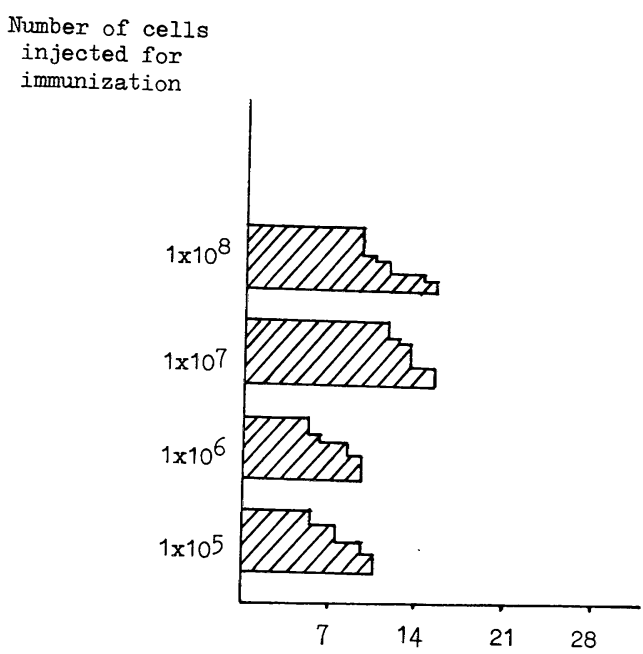

Days after infection

Fig. 2 Protective effect of living and killed cells of the $18 \mathrm{MI}$ strain against infection with $1 \times 10^{4}$ cells of the 116 strain. Infection was carried out 3 weeks after immunization. 
3. Chemical analysis of phenol extracts. The results of chemical analysis of fractions extracted with phenol $\mathrm{pH}$ 4 and $\mathrm{pH} 6$ are shown in Table 1 and 2, respectively. Each fraction contained 82 to $96 \%$ of RNA, except I-D fraction which contained a lot of DNA. Protein was contained at a concentration 1.4 to $6.6 \mu \mathrm{g}$ per $100 \mu \mathrm{g}$ of RNA. The ultraviolet adsorption spectra of these fractions are shown in Fig. 3. The ratio of $\mathrm{OD}_{260} / \mathrm{OD}_{230 \mathrm{n} \text { in }}$ and the ratio of $\mathrm{OD}_{260} /$ $\mathrm{OD}_{280 \mathrm{n} \text { in }}$ are also shown in Table 1 . The ratio of fraction I, I-D, III and IV extracted with phenol $\mathrm{pH} 4$ were 2.37 , $2.23,2.12$ and 2.19 , respectively.

Protective effect of phenol extract. Protective effects of each fraction extracted with phenol $\mathrm{pH} 4$ and $\mathrm{pH} 6$ are examined, and the results are shown in Fig. 4. Each fraction extracted with phenol $\mathrm{pH} 6$ had no preotective effect against infection with a virulent strain. On the other hand, two fractions (I and IV) extracted with phenol $\mathrm{pH} 4$ protected mice from the death by infection. However, in these cases, the survival rates were $50 \%$ and $30 \%$.

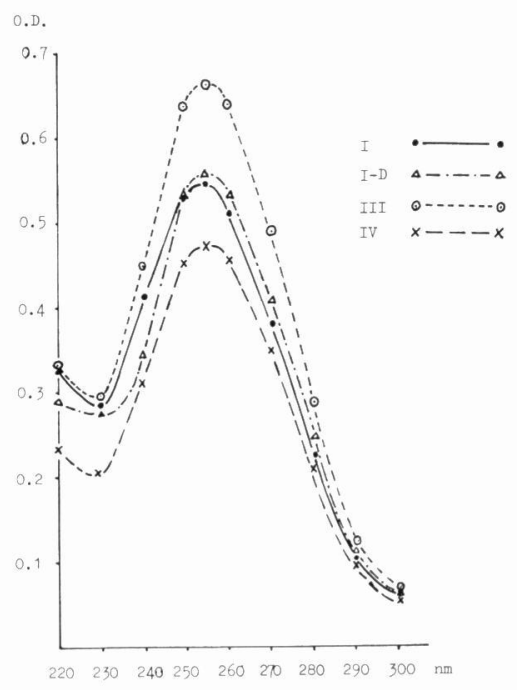

Fig. 3 Ultraviolet adsorption spectra of each fraction extracted from the $18 \mathrm{M}$ strain with phenol $\mathrm{pH} 4$.

TABLE 1

Chemical composition of each fraction extracted with phenol $p H 4$

\begin{tabular}{cccccc}
\hline Fraction & RNA & DNA & Protein/RNA & OD $_{260} / \mathrm{OD}_{230}$ & $\mathrm{OD}_{260} / \mathrm{OD}_{280}$ \\
\hline I & $96.3 \%$ & $1.6 \%$ & $3.9 \%$ & 1.78 & 2.37 \\
I - D & 65.6 & 48.5 & 4.1 & 1.91 & 2.23 \\
III & 92.7 & 6.0 & 1.4 & 2.19 & 2.12 \\
IV & 95.5 & 3.9 & 1.9 & 2.23 & 2.19 \\
\hline
\end{tabular}

TABLE 2

Chemical composition of each fraction extracted with phenol $p H 6$

\begin{tabular}{clcc} 
Fraction & RNA & DNA & Protein/RNA \\
\hline I & $82.4 \%$ & $12.9 \%$ & $3.5 \%$ \\
I -D & 74.0 & 23.6 & 3.2 \\
III & 96.4 & 2.0 & 1.7 \\
IV & 86.2 & 8.1 & 6.6
\end{tabular}


Mice immunized with fractions extracted with phenol $\mathrm{pH} 4$
Mice immunized with fractions extracted with phenol $\mathrm{pH} 6$

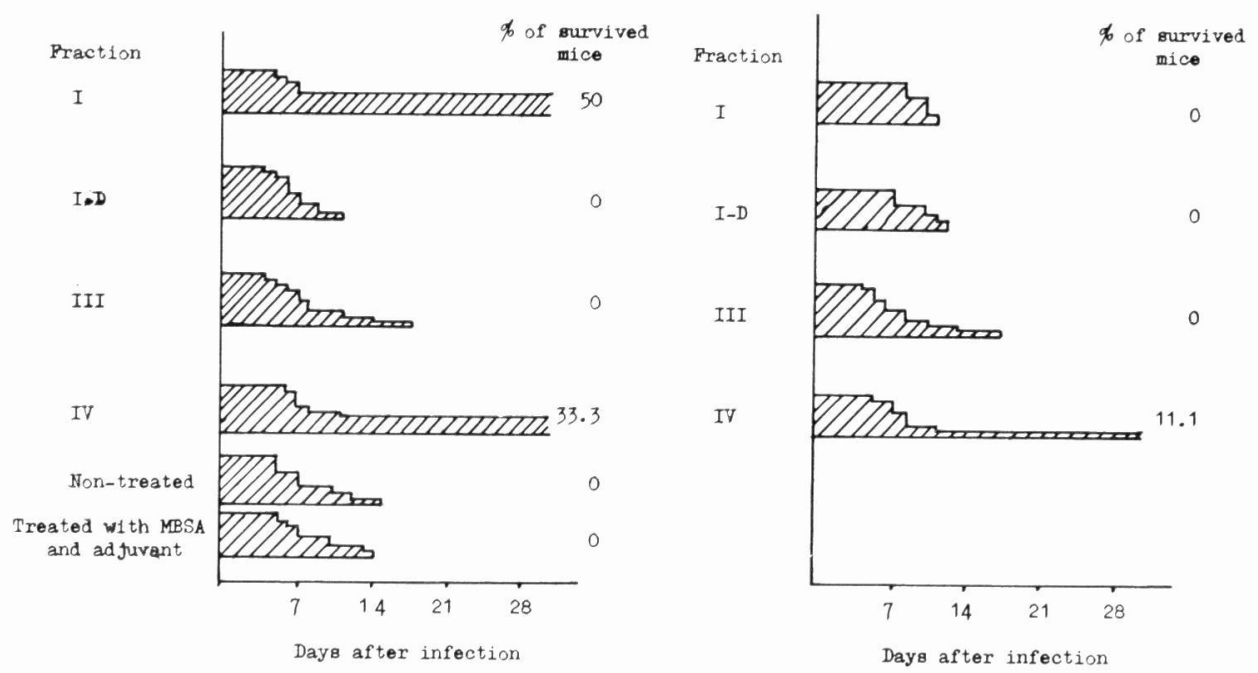

Fig. 4 Protective effect of each fraction extracted from $18 \mathrm{M}$ strain with phenol $\mathrm{pH} 4$ and 6 against infection with $1 \times 10^{5}$ cells of the 116 strain. Infection was carried out 3 weeks after last immunization.

\section{DISCUSSION}

In the experimental Salmonellosis, it has been well known that killed cells had no protective effect against infection with a virulent strain, though living cells were effective. In the present experiment, it was reconfirmed that these effects was reproducible. However, the true effective factor in living vaccine is not yet known.

Since the reports concerning the immunogenicity of ribosomal fraction in experimental tuberculosis were described by Youmans et al. ${ }^{3}{ }^{4}$ ), studies on the protective effects of ribosomal fraction and its components against infection were carried out by several investigators ${ }^{513}$. Smith et al. ${ }^{14}$ reported that RNA and protein isolated from the cell lysate showed low protection compared with ribosomal fraction against infection with Salmonella typhimurium. In our experiment, studies were carried out on the protective effect of RNA fraction extracted from destructed whole cells of attenuated strain of $\mathrm{S}$. enteritidis against infection with a virulent strain. It was shown that two RNA fractions extracted with phenol pH 4 protected mice from the death by infection, though all of RNA fractions extracted with phenol $\mathrm{pH} 6$ had no protective effect. As the fractions used in the present experiment contained small amounts of DNA and protein, besides a large volume of RNA, the problem on the relation of these components in protective effect is remained in further studies.

\section{ACKNOWLEDGEMENT}

The authors wish to acknowledge Dr. S. Mitsuhashi and Dr. M. Kawakami, Department of Microbiolgy, Gunma University School of Medicine, for kindly supplying us with SER$18 \mathrm{M}$ strain and $116-54$ strain of Salmonella enteritidis. 


\section{REFERENCES}

1) Mitsuhashi, S., KawaKami, M. and YamaGUCHI, M. : Studies on the experimental typhoid 1 A comparative study of living and killed vaccine against the infection of mice with Salmonella enteritidis. Jap. J. Exp. Med., 28, 249-258, 1958.

2 ) Kawakami, M., Osawa, N. and Mitsuhashi, M. : Experimental Salmonellosis VII Comparison of the immunizing effect of live vaccine and materials extracted from Salmonella enteritidis. J. Bacteriol., 92, 15851589, 1966.

3) Youmans, A. S. and Youmans, G. P. : Preparation of highly immunogenic ribosomal fraction of Mycobacterium tuberculosis by use of sodium dodecyl sulfate. J. Bacteriol., 91, 2139-2145, 1966.

4) Youmans, A.S. and Youmans, G. P. : Effect of trypsin and ribonuclease on the immunogenic activity of ribosomes and ribonucleic acid from Mycobaterium tuberculosis. J. Bacteriol., 91, 2146-2154, 1966.

5 ) Venneman, M. R. and Bigley, N. J. : Isolation and partial characterization of an immunogenic moiety obtained from Salmonella typhimurium. J. Bacteriol., 100, 140-148, 1969.

6 ) Sibatani, A. and Kimura, K. : Fractionation of RNA of animal cells with phenol. Protein Nucleic acid and Enzym, 8, 266277, 1963.
7) Ingle, J., Ley, J. L. and Holm, R. E. : Demonstration and characterization of DNAlike RNA in excised plant tissue. J. Mol. Biol., 11, 730-746, 1965.

8) Georgiev, G.P., Mantiva, V.L. and ZbalSKY, I. B. : RNA fraction in cell nuclei isolated by phenol and by sucrose-glycerophosphate. Biochem. Biophys. Acta. 37, 373-374, 1960.

9) Hagihara, Y. and Shikada, K. : The base composition of deoxyribonucleic acid isolated from Mycobacteria. Kekkaku, 44, 321-324, 1969.

10) Dishe, Z. : The Nucleic Acid, Vol. 1, p. 287, Academic Press N. Y.

11) Lowry, O. H., Rosenburough, N. J., Farr, A. L. and Rundall, R. J. : Protein measurement with the folin phenol reagent. J. Biol. Chem. 193, 265-275, 1951.

12) Plescia, O. J., Braun, W. and Palczuk, N. C. : Production of antibodies to denaturated deoxyribonucleic acid (DNA). Proc. N. A. S., 52, 279-285, 1964.

13) Jensen, R., Gregory, B., NAylor, J. and ActoR, P. : Isolation of protective somatic antigen from Vibrio cholerae (Ogawa) ribosomal preparations. Infection and Immunity, 6, 156-161, 1972.

14) Smith, R. A. and Bigley, N. J. : Ribonucleic acid-protein fraction of virulent Salmonella typhimurium as protective immunogens. Infection and Immuniy, 6, 377-383. 1972. 